\title{
SMAD6 wt Allele
}

National Cancer Institute

\section{Source}

National Cancer Institute. SMAD6 wt Allele. NCI Thesaurus. Code C52822.

Human SMAD6 wild-type allele is located within 15q21-q22 and is approximately $80 \mathrm{~kb}$ in length. This allele, which encodes mothers against decapentaplegic homolog 6 protein, plays a role in the regulation of both heart and blood vessel development and maintenance. 